\title{
Characteristics of Microorganisms Isolated from Blood Cultures at Nine University Hospitals in Korea during 2009
}

\author{
Hee-Jung Kim ${ }^{1}$, Nam Yong Lee ${ }^{1}$, Sunjoo Kim ${ }^{2,3}$, Jeong Hwan Shin ${ }^{4,5}$, Mi-Na Kim ${ }^{6}$, Eui-Chong Kim, \\ Sun Hoi Koo, Nam Hee Ryoo, Jae-Seok Kim ${ }^{10}$, Ji-Hyun $\mathrm{Cho}^{11}$ \\ ${ }^{1}$ Department of Laboratory Medicine \& Genetics, Samsung Medical Center, Sungkyunkwan University School of \\ Medicine, Seoul, ${ }^{2}$ Department of Laboratory Medicine, ${ }^{3}$ Institute of Health Sciences, Gyeongsang National University \\ School of Medicine, Jinju, ${ }^{4}$ Department of Laboratory Medicine, ${ }^{5}$ Paik Institute for Clinical Research, Inje University \\ College of Medicine, Busan, Department of Laboratory Medicine, ${ }^{6}$ Asan Medical Center and University of Ulsan \\ College of Medicine, ${ }^{7}$ Seoul National University Hospital, Seoul, ${ }^{8}$ College of Medicine, Chungnam National University, \\ Daejeon, ${ }^{9}$ School of Medicine, Keimyung University, Daegu, ${ }^{10}$ Hallym University College of Medicine, Seoul, \\ ${ }^{11}$ College of Medicine, Wonkwang University, Iksan, Korea
}

Background: Blood culture is important for determining the etiologic agents of bacteremia and fungemia. Analyses of blood culture results and antimicrobial susceptibility can provide clinicians with relevant information for the empirical treatment of patients. The present study was conducted to assess the frequencies and antimicrobial resistance patterns of clinically important microorganisms from nine hospitals.

Methods: Data including microbiological isolates and corresponding antimicrobial susceptibility test results were collected during 2009 from nine and five university hospitals, respectively. Microorganism identification was based on conventional methods. Antimicrobial susceptibility was tested using the VITEK II system or the Clinical and Laboratory Standards Institute disk diffusion method.

Results: Of 397,602 blood specimens cultured from nine hospitals, 34,708 (8.7\%) were positive for microorganisms. Excluding coagulase-negative Staphylococci (CoNS), Escherichia coli was the most com- mon isolate $(13.5 \%)$, followed by Staphylococcus aureus $(11.5 \%)$, Klebsiella pneumoniae $(6.5 \%)$ and Enterococcus faecium (3.4\%). The isolation rate of CoNS was $23.6 \%$, while that of ceftazidime-resistant $E$. coli showed geographic differences ranging from $11 \%$ to $28 \%$. Among the Gram-negative isolates, $A$. baumannii displayed the highest levels of resistance. The total isolation rate of the Candida species increased compared to the previous reported rate in Korea.

Conclusion: Among the isolates, CoNS was the most common, followed by $E$. coli and $S$. aureus. The gradual increase in the prevalence of extended-spectrum $\beta$-lactamase (ESBL) producers has contributed to the increase in multi-drug resistance among bacterial isolates from bloodstream infections. (Korean $\mathbf{J}$ Clin Microbiol 2011;14:48-54)

Key Words: Blood culture, Bacteremia, Antimicrobial susceptibility, Fungemia

\section{INTRODUCTION}

The isolation of bacteria from blood cultures is usually indicative of a serious invasive infection requiring urgent antimicrobial therapy. Different microorganisms have different antimicrobial susceptibilities and successful treatment is dependent on the prompt administration of the proper antimicrobial agents. Throughout the 1960s and 1970s, Gram-negative microor-

Received 1 December, 2010, Revised 3 March, 2011

Accepted 27 April, 2011

Correspondence: Nam Yong Lee, Department of Laboratory Medicine \& Genetics, Samsung Medical Center, Sungkyunkwan University School of Medicine, 50 Ilwon-dong, Gangnam-gu, Seoul 135-710, Korea. (Tel) 82-2-3410-2706, (Fax) 82-2-3410-2719, (E-mail) micro.lee@ samsung.com ganisms were most frequently isolated from patients with nosocomial bloodstream infections (BSI). Since then, the number of infections due to Gram-positive microorganisms has been increasing [1-3]. In addition, antibiotic resistance rates have been rising for all predominant microorganisms, including Staphylococcus aureus [2,4], coagulase-negative staphylococci (CoNS) [5], Enterococci [6], and Gram-negative pathogens [3,7,8]. In the face of emerging multi-resistant microorganisms, antimicrobial prophylaxis and treatment have become increasingly difficult. Additionally, timely and accurate epidemiologic information is needed to guide the choice of an appropriate empirical therapy. Candida BSIs have increased due to the use of broad-spectrum antibiotics and the increasing number of immunocompromised patients. Analyses of Candida BSIs have shown trends toward the selection for non-albicans Candida spe- 
cies, some of which are difficult to treat with first-generation azoles $[9,10]$.

Blood culture is important for the determination of the etiologic agent of bacteremia or fungemia. Analysis of blood culture results and antimicrobial susceptibility trends can provide clinicians with relevant information for the empirical treatment of patients with sepsis. Although there are data on blood culture from several hospitals in Korea, it is hard to acquire multicenter data encompassing various regions in Korea. This study was conducted to assess the frequency of medically important microorganisms and the antimicrobial susceptibilities of common pathogens.

\section{MATERIALS AND METHODS}

\section{Study design}

The surveillance network included data acquired from January 2009 to December 2009 at 9 university hospitals of various sizes (range, 700 2,700 beds) distributed throughout Korea (Asan Medical Center; Samsung Medical Center; Seoul National University Hospital; Gyeongsang National University Hospital; Inje University Paik Hospital; Chungnam National University Hospital; Dongsan Medical Hospital; Wonkwang University Hospital; and Kangdong Sacred Heart Hospital). Data regarding each microbiological isolate and corresponding antimicrobial susceptibility test results were collected using a standardized report form. The sizes of the intensive care units, emergency departments and disease distribution were outside the scope of this study.

\section{Microbiological methods}

Blood cultures were processed at the participating hospitals. The identification of blood isolates and susceptibility testing were performed according to the routine methods in use at the affiliated laboratories. All microbiological methods were consistent with the current Clinical and Laboratory Standards Institute (CLSI) guidelines [11]. Data from participating hospitals were used for analysis; however, the number of tested isolates for each antimicrobial agent varied because the participating laboratories did not have same susceptibility test panels. Although the bacteriologic profiles from blood cultures were obtained from 9 participating hospitals, in vitro antibiogram data for the bacterial isolates were available from only 5 out of 9 hospitals (Samsung Medical Center; Seoul National University Hospital; Inje University Paik Hospital; Chungnam National University Hospital; Wonkwang University Hospital).

1) Isolate frequency: The frequency of several commonly isolated microorganisms was determined. Among the Gram-positive cocci, the frequencies of $S$. aureus, Enterococcus faecium, and CoNS including Staphylococcus epidermidis were reviewed. Escherichia coli, Klebsiella pneumoniae, Pseudomonas aeruginosa and Acinetobacter baumanii were included as Gram-negative bacilli. For yeast, the frequencies of Candida albicans, Candida tropicalis, Candida parapsilosis, and Candida glabrata were investigated.

2) Antimicrobial susceptibility test: The antimicrobial resistance rates for several medically important microorganisms $(S$. aureus, E. faecium, Enterococcus faecalis, E. coli, K. pneumoniae, A. baumannii and $P$. aeruginosa) as well as $S$. epidermidis were included.

\section{RESULTS}

Of 397,602 blood specimens cultured from 9 laboratories, $34,708(8.7 \%)$ were positive for the microorganisms tested. The average positive blood culture rate at the 9 university hospitals was $8.6 \%(95 \% \mathrm{CI}, 7.5 \sim 9.7 \%)$, whereas the polymicrobial infection rate was as low as $0.3 \%(95 \% \mathrm{CI}, 0.2 \sim 0.4 \%)$.

\section{The frequency of Gram-positive cocci}

The total number of isolates varied according to the hospital, and may have been affected by the number of samples ordered. The average number of isolates was 4,401 (SD 2,456; range, $1.128 \sim 10,132)$. Among the approximately 35,000 isolates, the frequencies of $S$. aureus and E. faecium were $11.7 \%$ (95\% CI, 9.6 13.8\%) and 3.4\% (95\% CI, 1.9 5.0\%), respectively (Fig. 1). All but one institution showed more frequent isolation of $E$. faecium than E. faecalis (data not shown). CoNS isolated from $23.6 \%$ (95\% CI, 18.7 28.4\%) of samples. Among CoNS, S. epidermidis was most common at $12.1 \%$ (95\% CI, 9.6 14.6\%), followed by Staphylococcus hominis at 3.9\% (95\% CI, 2.3 $5.5 \%$ ). Three institutions had a CoNS isolation frequency greater than $30 \%$.

\section{The frequency of Gram-negative bacilli}

The most common Gram-negative microorganisms were $E$. coli $(13.5 \%$ [95\% CI, 11.6 15.3\%]) and $K$. pneumoniae $(6.5 \%$ [95\% CI, 5.3 7.7\%]). Common nosocomial pathogens such as A. baumannii and $P$. aeruginosa were isolated from $2.6 \%(95 \%$ CI, $1.8 \sim 3.4 \%$ ) and $2.5 \%$ (95\% CI, $1.6 \sim 3.3 \%$ ) of samples, respectively (Fig. 1).

\section{The frequency of yeasts}

C. albicans was the most common among the yeasts accounting for $2.3 \%(95 \% \mathrm{CI}, 1.6 \sim 3.6 \%)$ of the total isolates (Fig. 2). The frequencies of C. parapsilosis, C. tropicalis, and C. glabrata were $1.9 \%$ (95\% CI, 0.6 3.1\%), 1.4\% (95\% CI, 1.0 1.9\%), and $0.6 \%$ (95\% CI, $0.3 \sim 0.9 \%$ ), respectively (Fig. 2). At one institution, the isolation frequency of C. albicans was $6.1 \%$ and in another institution that of $C$. parapsilosis was $6.0 \%$.

\section{Antimicrobial resistance}

1) Gram-positive cocci: The antimicrobial resistance levels for the most common Gram-positive microorganisms causing BSIs are shown in Table 1 . Resistance to methicillin was detected in $69.8 \%$ of $S$. aureus and $84.7 \%$ of $S$. epidermidis isolates. The highest proportion of methicillin resistance in $S$. aureus isolates $(82.2 \%)$ was seen in the central region 
(Daejeon). Vancomycin resistance was not detected in either $S$. aureus or $S$. epidermidis isolates.

Ampicillin resistance rates for E. faecalis and E. faecium were $14.2 \%$ and $91.2 \%$, respectively. Notably, the rates of vancomycin resistance were highly correlated with enterococcal species. The proportion of resistance to vancomycin was $28.6 \%$ in E. faecium isolates and $0 \%$ in E. faecalis isolates. Geographic

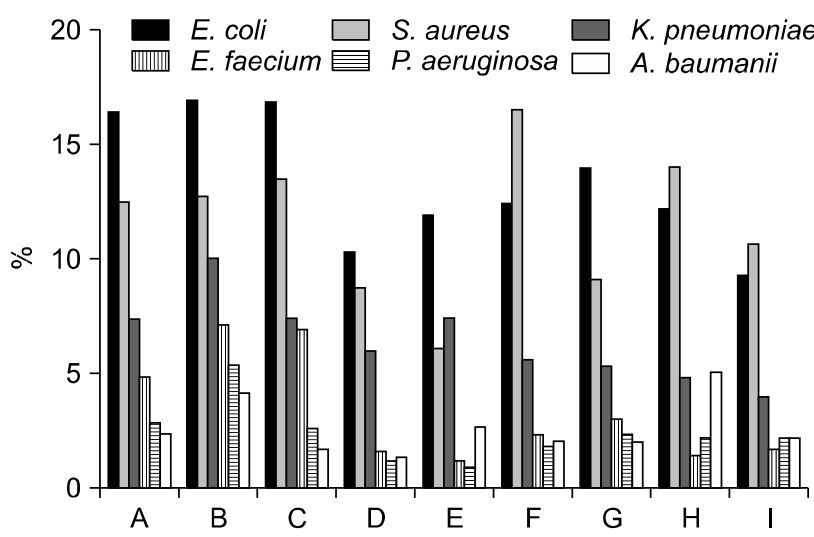

Fig. 1. The isolation frequencies of common bacteria from 9 hospitals. A, Asan Medical Center; B, Samsung Medical Center; C, Seoul National University Hospital; D, Gyeongsang National University Hospital; E, Inje University Paik Hospital; F, Chungnam National University Hospital; G, Dongsan Medical Hospital; H, Wonkwang University Hospital; I, Kangdong Sacred Heart Hospital. variation of vancomycin resistance in E. faecium was significant and ranged from $9 \%$ in the southwest (Iksan) to $46 \%$ in the southeast (Busan), with the central region (Seoul and Daejeon) having an intermediate level (18 35\%) (data not shown). Streptococcus pneumoniae isolates exhibited high proportions of resistance to tetracycline $(68.1 \%)$ and erythromycin $(61.5 \%)$. While $20.9 \%$ and $24.6 \%$ of isolates were resistant to penicillin and trimethoprim-sulfamethozaxole, respectively, cefotaxime and levofloxacin displayed good activity.

2) Gram-negative rods: Antimicrobial resistance levels for the most common Gram-negative microorganisms causing BSIs are

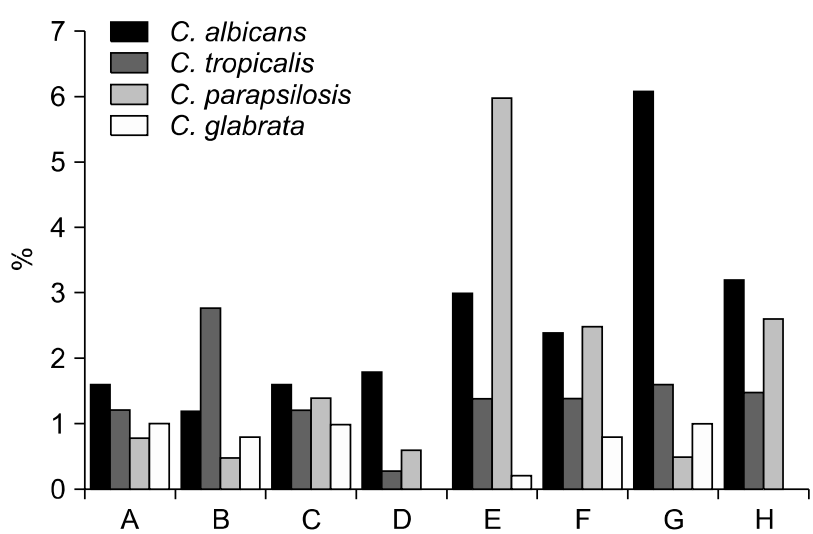

Fig. 2. The isolation frequencies of common yeasts from 9 hospitals. See Fig. 2 for designations for each hospital $(\mathrm{A} \sim \mathrm{H})$.

Table 1. Rates of antibiotic resistance among the most common Gram-positive bacteria causing bloodstream infections from 5 Korean hospitals in 2009

\begin{tabular}{|c|c|c|c|c|c|c|c|c|c|c|}
\hline & \multicolumn{2}{|c|}{$\begin{array}{c}\text { Staphylococcus } \\
\text { aureus }\end{array}$} & \multicolumn{2}{|c|}{$\begin{array}{l}\text { Staphylococcus } \\
\text { epidermidis }\end{array}$} & \multicolumn{2}{|c|}{$\begin{array}{l}\text { Enterococcus } \\
\text { faecium }\end{array}$} & \multicolumn{2}{|c|}{$\begin{array}{l}\text { Enterococcus } \\
\quad \text { faecalis }\end{array}$} & \multicolumn{2}{|c|}{$\begin{array}{l}\text { Streptococcus } \\
\text { pneumoniae }\end{array}$} \\
\hline & $\mathrm{N}$ & $\%$ resistance & $\mathrm{N}$ & $\%$ resistance & $\mathrm{N}$ & $\%$ resistance & $\mathrm{N}$ & $\%$ resistance & $\mathrm{N}$ & $\%$ resistance \\
\hline Ampicillin & ND & NA & ND & NA & 336 & 91.2 & 186 & 14.2 & ND & NA \\
\hline Penicillin & 1121 & 95.4 & 1032 & 96.8 & 336 & 92.1 & 186 & 15.7 & 49 & 20.9 \\
\hline Clindamycin & 1121 & 63.8 & 1032 & 65.9 & ND & NA & ND & NA & ND & NA \\
\hline Oxacillin & 1072 & 69.8 & 1032 & 84.7 & ND & NA & ND & NA & ND & NA \\
\hline QNP-DFP & 1072 & 0.2 & 1032 & 0.1 & ND & NA & ND & NA & ND & NA \\
\hline Cefotaxime* & ND & NA & ND & NA & ND & NA & ND & NA & 52 & 7.3 \\
\hline Cefotaxime $^{\dagger}$ & ND & NA & ND & NA & ND & NA & ND & NA & 52 & 5.4 \\
\hline Erythromycin & 1121 & 61.0 & 1032 & 71.3 & ND & NA & ND & NA & 59 & 61.5 \\
\hline Ciprofloxacin & 1121 & 56.4 & 1032 & 58.8 & ND & NA & ND & NA & ND & NA \\
\hline Levofloxacin & 731 & 62.4 & 656 & 26.2 & ND & NA & ND & NA & 59 & 7.9 \\
\hline Gentamicin & 947 & 61.4 & 1032 & 63.7 & ND & NA & ND & NA & ND & NA \\
\hline HL Gentamicin & ND & NA & ND & NA & 325 & 49.2 & 186 & 37.9 & ND & NA \\
\hline HL Streptomycin & ND & NA & ND & NA & 325 & 8.0 & 186 & 16.9 & ND & NA \\
\hline Rifampin & 502 & 2.8 & 1032 & 16.2 & ND & NA & ND & NA & ND & NA \\
\hline Tetracycline & 1121 & 55.8 & 1032 & 22.9 & ND & NA & ND & NA & 59 & 68.1 \\
\hline TMP-SMX & 502 & 7.3 & 522 & 49.7 & ND & NA & ND & NA & 34 & 24.6 \\
\hline Vancomycin & 1072 & 0.0 & 1032 & 0.0 & 336 & 28.6 & 186 & 0.0 & 52 & 0.0 \\
\hline
\end{tabular}

*Meningitis, CLSI-recommended resistant MIC breakpoint $2 \geq \mu \mathrm{g} / \mathrm{mL},{ }^{\dagger}$ Non-meningitis, CLSI-recommended resistant MIC breakpoint $4 \geq$ $\mu \mathrm{g} / \mathrm{mL}$.

Abbreviations: ND, not done; NA, not applicable; QNP-DFP, quinupristin-dalfopristin; HL, high-level; TMP-SMX, trimethoprim-sulfamethoxazole. 
shown in Table 2. E. coli isolates displayed relatively high resistance to ampicillin (63.4\%), piperacillin (44.2\%), trimethoprim-sulfamethoxazole (37.0\%) and ciprofloxacin (36.6\%). However, all cephalosporins and gentamicin displayed relatively good activity. Of the K. pneumoniae isolates, $96.8 \%$ and $71.5 \%$ were resistant to ampicillin and piperacillin, respectively. Only imipenem and meropenem demonstrated in vitro activity in at least $90 \%$ of $K$. pneumoniae isolates. Ceftazidime resistance was found in $19.9 \%$ of $E$. coli isolates and in $24.2 \%$ of $K$. pneumoniae isolates. Among the Gram-negative isolates, A. baumannii displayed the highest levels of resistance. A high proportion of A. baumannii isolates were resistant to ceftazidime (56.4\%), gentamicin (61.2\%) and ciprofloxacin (62.0\%). A total of $34.2 \%$
A. baumannii isolates showed resistance to imipenem and 54.4\% were resistant to meropenem. Of the $P$. aeruginosa isolates, $21.5 \%$ were resistant to ceftazidime and $25.0 \%$ were resistant to imipenem.

\section{DISCUSSION}

The positive blood culture rate ranged between $6.4 \%$ and $11.9 \%$ in this study, which is similar to or higher than that reported by single-institution studies in Korea (4.6 9.6\%) [12-14]. The positive rate in blood culture varies with multiple factors such as patient characteristics, culture methodology and the frequency with which blood cultures are ordered by clinicians.

Table 2. Rates of antibiotic resistance among the most common Gram-negative rods causing bloodstream infections from 5 Korean hospitals in 2009

\begin{tabular}{|c|c|c|c|c|c|c|c|c|}
\hline & \multicolumn{2}{|c|}{ Escherichia coli } & \multicolumn{2}{|c|}{ Klebsiella pneumoniae } & \multicolumn{2}{|c|}{ Acinetobacter baumannii } & \multicolumn{2}{|c|}{ Pseudomonas aeruginosa } \\
\hline & $\mathrm{N}$ & $\%$ resistance & $\mathrm{N}$ & $\%$ resistance & $\mathrm{N}$ & $\%$ resistance & $\mathrm{N}$ & $\%$ resistance \\
\hline Ampicillin & 1537 & 63.4 & 702 & 96.8 & ND & NA & ND & NA \\
\hline Amoxicillin-Clavulanate & ND & NA & 702 & 17.8 & ND & NA & ND & NA \\
\hline Piperacillin & 721 & 44.2 & 597 & 71.5 & 200 & 57.2 & 263 & 26.2 \\
\hline Piperacillin-Tazobactam & 1129 & 10.2 & 736 & 12.5 & 200 & 49.9 & 263 & 20.6 \\
\hline Ticarcillin & ND & NA & ND & NA & ND & NA & 250 & 32.9 \\
\hline Ticarcilin-Clavulanate & ND & NA & ND & NA & 151 & 53.1 & ND & NA \\
\hline Cefazolin & 832 & 23.9 & 394 & 30.4 & ND & NA & ND & NA \\
\hline Cefoxitin & $\mathrm{ND}$ & NA & 736 & 14.0 & ND & NA & ND & NA \\
\hline Cefotaxime & 1537 & 19.1 & 736 & 27.2 & ND & NA & ND & NA \\
\hline Ceftazidime & 1129 & 19.9 & 736 & 24.2 & 226 & 56.4 & 250 & 21.5 \\
\hline Cefepime & 1113 & 19.7 & 736 & 26.7 & 226 & 55.8 & 263 & 18.1 \\
\hline Imipenem & 1456 & 0.2 & 702 & 0.4 & 226 & 34.2 & 250 & 25.0 \\
\hline Meropenem & 1456 & 0.1 & 702 & 0.7 & 226 & 54.4 & 250 & 19.0 \\
\hline Aztreonam & ND & NA & 736 & 28.0 & ND & NA & 250 & 20.9 \\
\hline Ciprofloxacin & 913 & 36.6 & 394 & 17.5 & 207 & 62.0 & 263 & 18.8 \\
\hline Levofloxacin & $\mathrm{ND}$ & NA & 394 & 13.4 & 226 & 43.4 & 157 & 32.5 \\
\hline Gentamicin & 1537 & 27.0 & 736 & 19.4 & 226 & 61.2 & 263 & 13.3 \\
\hline Amikacin & ND & NA & 736 & 13.7 & ND & NA & 263 & 6.7 \\
\hline Tobramycin & 1537 & 14.0 & 736 & 19.8 & 226 & 47.2 & 263 & 11.4 \\
\hline TMP-SMX & 1032 & 37.0 & 509 & 23.3 & ND & NA & 126 & 98.4 \\
\hline
\end{tabular}

Abbreviations: See Table 1.

Table 3. Rank order of microorganisms or microorganism groups most frequently isolated from blood samples

\begin{tabular}{|c|c|c|c|c|c|c|}
\hline \multirow[b]{2}{*}{ Rank } & \multicolumn{6}{|c|}{ Study (period) } \\
\hline & $\begin{array}{l}\text { This study } \\
\text { (2009) }\end{array}$ & $\begin{array}{l}\text { Kang et al [13] } \\
(2003 \sim 2007)\end{array}$ & $\begin{array}{l}\text { Ahn et al [14] } \\
(2002 \sim 2005)\end{array}$ & $\begin{array}{l}\text { Koh et al [12] } \\
(1994 \sim 2003)\end{array}$ & $\begin{array}{c}\text { Weinstein et al [22] } \\
\text { (1990s) }\end{array}$ & $\begin{array}{c}\text { Cockerill et al [15] } \\
\quad(1996 \sim 1997)\end{array}$ \\
\hline 1 & CoNS & CoNS & CoNS & CoNS & S. aureus & S. aureus \\
\hline 2 & E. coli & E. coli & E. coli & E. coli & E. coli & E. coli \\
\hline 3 & S. aureus & S. aureus & S. aureus & S. aureus & CoNS & CoNS \\
\hline 4 & K. pneumoniae & K. pneumoniae & S. maltophilia & $S V G$ & K. pneumoniae & Enterococci \\
\hline 5 & E. faecium & S. pneumoniae & S. marcescens & Enterococci & Enterococci & C. albicans \\
\hline
\end{tabular}

Abbreviations: CoNS, coagulase-negative staphylococci; S. aureus, Staphylococcus aureus; E. coli, Escherichia coli; K. pneumoniae, Klebsiella pneumoniae; S. maltophilia, Stenotrophomonas maltophilia; SVG. Streptococcus viridans group; E. faecium, Enterococcus faecium; S. marcescens, Serratia marcescens; C. albicans, Candida albicans. 
The relative frequencies of isolates among approximately 35,000 microorganisms isolated from blood culture were analyzed. Excluding CoNS, E. coli $(13.5 \%)$ was the most common isolate, followed by $S$. aureus $(11.5 \%)$, and $K$. pneumoniae (6.5\%). E. faecium, approximately $30 \%$ of which was vancomycin-resistant Enterococci, accounted for 3.4\% of all isolates. The nonfermentive Gram-negative rods, A. baumanii and $P$. aeruginosa, had frequencies of $2.6 \%$ and $2.5 \%$, respectively. Among the isolates, CoNS (23.6\%) was the most frequently isolated microorganism and the difference between the highest and the lowest isolation frequencies was 2.5 -fold.

The frequencies of isolates differ according to the study (Table 3). In Korea, Koh et al. [12] reported CoNS, E. coli, S. aureus, alpha-hemolytic streptococci, Enterococci, and K. pneumoniae in decreasing order. In another study, Ahn et al. [14] listed CoNS, E. coli, and S. aureus, followed by Stenotrophomonas maltophilia and Serratia marcescens. Cockerill et al. [15] analyzed data from 1996 1997 in the United States and reported S. aureus, E. coli, CoNS, Enterococci, C. albicans, and $P$. aeruginosa in decreasing order. Isolate frequency can be affected by skin disinfection methods, composition of the patient group as well as the number of blood culture.

According to the data, obligate anaerobes were rarely isolated and thus were excluded in this study. The reason for the low incidence of obligate anaerobic bacteremia might be the prophylactic usage of antibiotics before surgery as well as wide use of broad-spectrum antibiotics [16].

With the increased use of aggressive interventions that disrupt the integrity of skin or mucosa and vascular catheters, the likelihood that CoNS will cause infections is increasing. CoNS grow slowly or grow in only one of several replicate cultures if it is a skin contaminant [17-19]. Given the high likelihood that isolation of CoNS from blood cultures is usually indicative of contamination, determining the likelihood of true bacteremia can be challenging for clinicians, and this is beyond the scope of this study.

The use of broad-spectrum antibiotics or immunosuppressants, transplantation, and aging are risk factors for fungal infections [20-22]. As the mortality rate of fungemia is very high, it should be reported with urgency in order for timely treatment with antifungal agents. The most common yeasts in this study were $C$. albicans, followed by C. parapsilosis, C. tropicalis, and C. glabrata. The total isolation rate of Candida spp. exceeded $6 \%$, which is higher than the $2.8 \%$ reported by Ahn et al. [14]. Lee et al. [21] reported the frequencies of yeasts such as C. albicans $(49 \%)$, C. parapsilosis $(22 \%)$, C. tropicalis $(14 \%)$, and C. glabrata (11\%) in a multicenter study; results that are similar to those from our current study.

The rate of resistance to methicillin among $S$. aureus ( $\sim 70 \%)$ was consistent with recent data from other studies in Korea [14,23]. Ampicillin resistance in E. faecalis found in our study is relatively high $(14.2 \%)$ compared to that in a previous study in Korea $(\sim 0 \%)$. We observed that the rate of resistance to ampicillin in E. faecium infections was as high as $90 \%$ and was comparable to rates reported in recent studies from Korea [12,24]. In our study, the prevalence of resistance to vancomycin among E. faecium isolates $(25 \%)$ was similar to the prevalence previously reported in Korea (29 33\%) [12,23]. The high rates of resistance to ampicillin and vancomycin should be considered in the empirical treatment of E. faecium.

Although the number of $S$. pneumoniae isolates in this study was small, the prevalence of penicillin resistance was noticeably lower in this study (21\%) in comparison to $55 \%$ reported by Song et al. [25]. In January 2008, the CLSI published new $S$. pneumoniae breakpoints for penicillin. Many studies that applied the new CLSI guidelines reported an increase in the penicillin susceptibility of $S$. pneumoniae strains isolated from blood [26,27].

Increases in the prevalence of extended-spectrum $\beta$-lactamase (ESBL)-producing E. coli and $K$. pneumoniae have been reported in Korea [12,28]. In this study, when the resistance to ceftazidime was used as a marker for the potential presence of ESBL, $20 \%$ of $E$. coli and $24 \%$ of $K$. pneumoniae isolates were potential carriers of these enzymes. According to a previous study that included 12 hospitals [28], the proportion of ESBLproducers was $9.1 \%$ (range, $2.0 \sim 19.6 \%$ ) of the E. coli and $29.2 \%$ (range, $10.0 \sim 60.8 \%$ ) of the K. pneumoniae isolates. Koh et al. [12] reported a wide range of cefotaxime resistance for $E$. coli and $K$. pneumoniae isolates depending on different survey years $(2 \sim 28 \%$ and $4 \sim 31 \%$, respectively). The incidence of ESBL-producing isolates varies according to country, region and even hospital. We also found marked geographic differences in the occurrence of ceftazidime resistance, ranging from $11 \%$ to $28 \%$ of $E$. coli isolates and from $12 \%$ to $51 \%$ of $K$. pneumoniae isolates, respectively.

In conclusion, the frequency of common pathogens was reported based on multi-institutional data from 2009. These data suggest the need to review the possibility of an outbreak of some pathogens such as C. albicans and C. parapsilosis. Among the isolates, CoNS was the most common, followed by $E$. coli and $S$. aureus. The high prevalence of ESBLs has contributed to the finding of multi-drug resistance among $K$. penumoniae and $E$. coli. Furthermore, A. baumannii and $P$. aeruginosa isolates displaying resistance to many antibiotics including carbapenem make the selection of optimal antibiotics difficult. Adequate management of infections due to these multi-drug resistant pathogens requires knowledge of microbiological epidemiology and practices to control their spread.

\section{REFERENCES}

1. National Nosocomial Infections Surveillance System. National Nosocomial Infections Surveillance (NNIS) System Report, data summary from January 1992 through June 2004, issued October 2004. Am J Infect Control 2004;32:470-85.

2. Edmond MB, Wallace SE, McClish DK, Pfaller MA, Jones RN, Wenzel RP. Nosocomial bloodstream infections in United States hospitals: a three-year analysis. Clin Infect Dis 1999;29:239-44.

3. Diekema DJ, Pfaller MA, Jones RN; SENTRY Participants Group. 
Age-related trends in pathogen frequency and antimicrobial susceptibility of bloodstream isolates in North America: SENTRY Antimicrobial Surveillance Program, 1997 2000. Int J Antimicrob Agents 2002;20:412-8.

4. Smith TL and Jarvis WR. Antimicrobial resistance in Staphylococcus aureus. Microbes Infect 1999;1:795-805.

5. Diekema DJ, Pfaller MA, Schmitz FJ, Smayevsky J, Bell J, Jones RN, et al; SENTRY Partcipants Group. Survey of infections due to Staphylococcus species: frequency of occurrence and antimicrobial susceptibility of isolates collected in the United States, Canada, Latin America, Europe, and the Western Pacific region for the SENTRY Antimicrobial Surveillance Program, 1997-1999. Clin Infect Dis 2001;32 Suppl 2:S114-32.

6. Doern GV, Jones RN, Pfaller MA, Erwin M, Ramirez-Rhonda C. Multicenter evaluation of the in vitro activity of six broad-spectrum beta-lactam antimicrobial agents in Puerto Rico. The Puerto Rico Antimicrobial Resistance Study Group. Diagn Microbiol Infect Dis 1998;30:113-9.

7. Diekema DJ, Pfaller MA, Jones RN, Doern GV, Winokur PL, Gales $\mathrm{AC}$, et al. Survey of bloodstream infections due to gram-negative bacilli: frequency of occurrence and antimicrobial susceptibility of isolates collected in the United States, Canada, and Latin America for the SENTRY Antimicrobial Surveillance Program, 1997. Clin Infect Dis 1999;29:595-607.

8. Heinemann B, Wisplinghoff H, Edmond M, Seifert H. Comparative activities of ciprofloxacin, clinafloxacin, gatifloxacin, gemifloxacin, levofloxacin, moxifloxacin, and trovafloxacin against epidemiologically defined Acinetobacter baumannii strains. Antimicrob Agents Chemother 2000;44:2211-3.

9. Diekema DJ, Messer SA, Brueggemann AB, Coffman SL, Doern GV, Herwaldt LA, et al. Epidemiology of candidemia: 3-year results from the emerging infections and the epidemiology of Iowa organisms study. J Clin Microbiol 2002;40:1298-302.

10. Hajjeh RA, Sofair AN, Harrison LH, Lyon GM, Arthington-Skaggs BA, Mirza SA, et al. Incidence of bloodstream infections due to Candida species and in vitro susceptibilities of isolates collected from 1998 to 2000 in a population-based active surveillance program. J Clin Microbiol 2004;42:1519-27.

11. National Committee for Clinical Laboratory Standards. Performance standards for antimicrobial susceptibility testing. Twenlfth informational supplement, M100-S20. Wayne, PA: National Committee for Clinical Laboratory Standards. 2010.

12. Koh EM, Lee SG, Kim CK, Kim M, Yong D, Lee K, et al. Microorganisms isolated from blood cultures and their antimicrobial susceptibility patterns at a university hospital during 1994 2003. Korean J Lab Med 2007;27:265-75.

13. Kang SH and Kim YR. Characteristics of microorganisms isolated from blood cultures at a university hospital located in an island region during 2003 2007. Korean J Clin Microbiol 2008;11:11-7.

14. Ahn GY, Jang SJ, Lee SH, Jeong OY, Chaulagain BP, Moon DS, et al. Trends of the species and antimicrobial susceptibility of microorganisms isolated from blood cultures of patients. Korean $\mathrm{J}$ Clin Microbiol 2006;9:42-50.

15. Cockerill FR 3rd, Wilson JW, Vetter EA, Goodman KM, Torgerson CA, Harmsen WS, et al. Optimal testing parameters for blood cultures. Clin Infect Dis 2004;38:1724-30.

16. Hall KK and Lyman JA. Updated review of blood culture contamination. Clin Microbiol Rev 2006;19:788-802.

17. Bates DW, Goldman L, Lee TH. Contaminant blood cultures and resource utilization. The true consequences of false-positive results. JAMA 1991;265:365-9.

18. Shafazand $\mathrm{S}$ and Weinacker AB. Blood cultures in the critical care unit: improving utilization and yield. Chest 2002;122:1727-36.

19. Souvenir D, Anderson DE Jr, Palpant S, Mroch H, Askin S, Anderson J, et al. Blood cultures positive for coagulase-negative staphylococci: antisepsis, pseudobacteremia, and therapy of patients. J Clin Microbiol 1998;36:1923-6.

20. Bryan CS. Clinical implications of positive blood cultures. Clin Microbiol Rev 1989;2:329-53.

21. Lee JS, Shin JH, Lee K, Kim MN, Shin BM, Uh Y, et al. Species distribution and susceptibility to azole antifungals of Candida bloodstream isolates from eight university hospitals in Korea. Yonsei Med J 2007;48:779-86.

22. Weinstein MP, Towns ML, Quartey SM, Mirrett S, Reimer LG, Parmigiani G, et al. The clinical significance of positive blood cultures in the 1990s: a prospective comprehensive evaluation of the microbiology, epidemiology, and outcome of bacteremia and fungemia in adults. Clin Infect Dis 1997;24:584-602.

23. Kim SY, Lim G, Kim MJ, Suh JT, Lee HJ. Trends in five-year blood cultures of patients at a university hospital (2003 2007). Korean J Clin Microbiol 2009;12:163-8.

24. Lee K, Lim CH, Cho JH, Lee WG, Uh Y, Kim HJ, et al; KONSAR Group. High prevalence of ceftazidime-resistant Klebsiella pneumoniae and increase of imipenem-resistant Pseudomonas aeruginosa and Acinetobacter spp. in Korea: a KONSAR program in 2004. Yonsei Med J 2006;47:634-45.

25. Song JH, Jung SI, Ko KS, Kim NY, Son JS, Chang HH, et al. High prevalence of antimicrobial resistance among clinical Streptococcus pneumoniae isolates in Asia (an ANSORP study). Antimicrob Agents Chemother 2004;48:2101-7.

26. Kim KH, Kim JE, Park SH, Song YH, Ahn JY, Park PW, et al. Impact of revised penicillin breakpoints for Streptococcus pneumoniae (CLSI M100-S18) on the penicillin susceptibility rate. Korean J Clin Microbiol 2010;13:68-72.

27. Centers for Disease Control and Prevention (CDC). Effects of new penicillin susceptibility breakpoints for Streptococcus pneumoniae-United States, 2006 2007. MMWR Morb Mortal Wkly Rep 2008; 57:1353-5.

28. Hong SG, Kim S, Jeong SH, Chang CL, Cho SR, Ahn JY, et al. Prevalence \& diversity of extended-spectrum beta-lactamase- producing Escherichia coli and Klebsiella pneumoniae isolates in Korea. Korean J Clin Microbiol 2003;6:149-55. 
$=$ 국문초록=

\section{9년 9게 대학병원의 혈액배양에서 흔히 분리된 균주 및 항균제 내성 양상}

${ }^{1}$ 성균관대학교 의과대학 삼성서울병원, ${ }^{2}$ 경상대학교 의학전문대학원, ${ }^{4}$ 인제대학교 의과대학, ${ }^{6}$ 울산대학교 의과대학 서울아산병원, ${ }^{7}$ 서울대학교병원, ${ }^{8}$ 충남대학교 의과대학, ${ }^{9}$ 계명대학교 의과대학, ${ }^{10}$ 한림대학교 의과대학, ${ }^{11}$ 원광대학교 의과대학 진단검사의학교실, ${ }^{3}$ 경상대학교 의학전문대학원 건강과학연구원, ${ }^{5}$ 백인제기념 임상의학연구소

김희정 ${ }^{1}$, 이남용 $^{1}$, 김선주 ${ }^{2,3}$, 신정환 $^{4,5}$, 김미나 $^{6}$, 김의종 $^{7}$, 구선회 $^{8}$, 류남희 $^{9}$, 김재석 $^{10}$, 조지현 ${ }^{11}$

배경: 혈액배양은 균혈증과 진균혈증의 원인균을 밝히는데 필수적인 방법으로 원인 균주와 항균제 감수성 결과를 파악 함으로써 임상에서 적절하고 경험적인 치료법을 선택할 수 있도록 유용한 정보를 제공한다. 이에 본 연구에서는 9개 병원을 대상으로 임상적으로 중요한 세균들의 분리율과 항균제 감수성 양상에 대하여 알아보고자 하였다.

방법: 2009년 1월부터 12월까지 1년간 9개 병원에서 혈액 배양이 의뢰된 검체를 대상으로 혈액배양 양성으로 나온 균종 의 결과와 이 중 5 개 병원에서 제공한 항균제 감수성 결과를 분석하였다. 혈액배양은 통상적인 혈액배양법을 시행하였고 균의 동정 및 항균제 감수성 검사는 VITEK II 장비 또는 Clinical and Laboratory Standards Institute 디스크법으로 시행하였 다.

결과: 혈액배양이 의뢰된 총 검체수는 397,602 이었고 이 중 $34,708(8.7 \%)$ 는 배양 결과 양성 균주를 보였다. 분리된 균주 중에 coagulase negative Staphylococci (CoNS)를 제외하였을 때 가장 흔한 병원균은 Escherichia coli (13.5\%)였고, 다음으로 Staphylococcus aureus (11.5\%), Klebsiella pneumoniae (6.5\%), Enterococcus faecium (3.4\%) 순이었다. 한편, CoNS가 전체 중 23.6\%로 가장 흔히 분리되었다. Ceftazidime 내성 E. coli 비율이 증가하고 있었으며 지역에 따라 $11 \sim 28 \%$ 로 차이를 보였다. 그람 음성 분리주 중 Acinetobacter baumannii가 가장 고도 내성을 보였으며 총 Candida 종의 분리율은 우리나라 에서 이전에 보고된 바 보다 높아졌다.

결론: 혈액 배양에서 분리된 균주 중에 CoNS가 가장 흔히 분리되었고 다음으로는 E. coli, S. aureus 순이었다. 점차 ESBL 양성 균주가 늘어나고 있는 추세는 균혈증에서 분리되는 다제내성균이 증가하는 데 기여하고 있는 것으로 생각된다. [대한임상미생물학회지 2011;14:48-54]

교신저자 : 이남용, $135-710$, 서울시 강남구 일원동 50

성균관대학교 의과대학 삼성서울병원 진단검사의학과

Tel: 02-3410-2706, Fax: 02-3410-2719

E-mail: micro.lee@samsung.com 